\title{
FORMULATION AND EVALUATION OF EFFERVESCENT TABLET FROM TAMPOI FRUIT EXTRACT (BACCAUREA MACROCARPA)
}

\author{
Ika Avrilina Haryono, Noval \\ Universitas Sari Mulia, Banjarmasin, South Borneo
}

\begin{abstract}
Background: Tampoi is one of the plants commonly found in East Kalimantan. It contains secondary metabolites in the form of saponins, flavonoids and alkaloids, and antioxidant activity. This study aimed to determine the good formula for making effervescent tablets from tampon fruit extract with a variety of dose $\mathrm{K}_{3} \mathrm{O}$.

Subjects and Method: This was an experimental study conducted at the Pharmaceutical Technology Laboratory, Universitas Sari Mulia, Banjarmasin, South Borneo from March to August 2021. The dependent variable was dissolution time. The independent variable was Tampoi fruit dose. The effervescent tablets were obtained from the extract of the Tampoi fruit (Baccaurea macrocarpa) and categorized into 4 different doses, including F1 (0.5\%), F2 (1.8\%), F3 (5\%), F4 (18\%). Fruit extracts were made in powder form. The four effervescent tablets were compared with each other on dissolution time using Copley Scientific.

Results: The effervescent tablets of tampon fruit in group F1 (0.5\%) showed the shortest dissolution time (01.99 minutes). Tampoi fruit extract in the form of effervescent powder met the requirement of the angle of repose test.

Conclusion: The best formula for tablet preparation of tampoi fruit extract with a concentration of PVP K30 = 0.5 mg with shortest dissolution time (01.99 minutes).
\end{abstract}

Keywords: antioxidant, tampoi fruits, tablet effervescent

\section{Correspondence:}

Ika Avrilina Haryono. Universitas Sari Mulia. Jl. Pramuka 2 Banjarmasin, South Borneo. Email: ika.avrilina@yahoo.com. Mobile: 08115669009 